\title{
What is 'International Administrative Law'? The Adequacy of this Term in Various Judgments of International Administrative Tribunals
}

\author{
Shinichi Ago*
}

\begin{abstract}
This chapter examines the adequacy of using the term 'international administrative law' in international administrative tribunal decisions, and finds it wanting. Whilst it is accepted that there is a set of legal rules applied by administrative tribunals established by international organizations to resolve employment-related disputes, it is misleading to term this 'international administrative law'. This chapter argues, both that 'international administrative law' has a literal legal meaning more aptly applied to the unique treaty-based legal regimes of international organizations, and that international administrative law' obscures uncertainty about the sources of law governing the employment relationships of inter-governmental institutions. This leads to confusion between substantive law and procedural law applied by international administrative tribunals together with a tendency to refer to 'international administrative law' whenever the tribunal could not clearly say what law they were applying.
\end{abstract}

\section{Introduction}

The notion of 'international administrative law' is frequently referred to by judges of international administrative tribunals (IATs), as well as applicants and respondents in the proceedings of those tribunals. Many seminars organized by IATs use the term 'international administrative law'. ${ }^{\text {The notion, }}$ however, is far from self-explanatory. It surely depicts an important aspect of

* Shinichi Ago, Professor at Ritsumeikan University, Kyoto, Japan, ago-law@fc.ritsumei.ac.jp. This chapter is written in my academic capacity, and not as a judge serving on the Asian Development Bank Administrative Tribunal. This chapter does not necessarily reflect the views of the Asian Development Bank or its members.

1 For example, a symposium organized by the IMF Administrative Tribunal in April 2014 on the occasion of its 2oth anniversary was entitled 'The Future of International Administrative 
the legal relationship between international organizations and their employees, but the use of the term by IATs has not been entirely clear.

Rather than being a lex specialis of the employment relations of international organizations, the literal legal meaning of 'international administrative law' suggests instead a set of rules in international law that pertains mostly to the activities of international organizations in the execution of their mandates. This is a whole system of international procedural law, 'administrating' or 'executing' the substantive law of international organizations, which support international public interests. When the United Nations (UN) General Assembly establishes a subsidiary organ, such as the UN Development Programme (UNDP) or a peace-keeping operation, it executes one of its mandates under the UN Charter and plays a role as the executive power of the organization. The resolution establishing a subsidiary organ, in this case, is an international institutional law with fully binding force, a substantive 'international administrative law', in other words. When the UNDP enters into a working agreement with a government or another international body, such as UN Specialized Agencies, or even with private enterprises in conducting its technical assistance activities, these agreements or contracts constitute procedural 'international administrative law'.

The UN Security Council decisions are the same. Being an executory organ of the UN, the Security Council is performing an administrative act by making decisions under Article 25 of the UN Charter, among others, to maintain peace and security. In the controversial case of Kadiv Commission, a decision by the UN Security Council judged by the Court of Justice of the EU to be infringing Mr. Kadi's human rights (not properly heard before the confiscation of his assets) was nothing but an 'international administrative law', a law enacted by a UN organ to execute its function of maintaining peace and security. ${ }^{2}$ All these decisions are 'international administrative law', in the literal legal sense of the term. If we accept the old theory of Georges Scelle of dedoublement fonction$n e l$, even an administrative act in the domestic legal system can also be an 'international administrative law' at the same time. ${ }^{3}$ In other words, custom officers at the airport confiscating products being imported against the provisions of the Convention on International Trade in Endangered Species of Wild Fauna and Flora (known as the Washington Convention) are not only national

Law: Harmonization? Fragmentation? Dialogue?' < https://www.imf.org/external/imfat/pdf/ Symposium3.pdf $>$ accessed 18 November 2019.

2 ECJ, Yassin Abdullah Kadi, Al Barakaat International Foundation $v$ Council of the European Union et al. (2008).

3 Scelle, 'Le phénomène juridique du dédoublement fonctionnel' 1956. 
administrative officers exercising their domestic administrative power, but at the same time are agents of public international law, in this case the Washington Convention. The customs officers would thus be executing 'international administrative law'.

IATs, on the other hand, are judicial bodies that are not performing executive functions of the international organizations in a strict sense. Their decisions are not administrative acts, but judicial ones and they are not applying 'international administrative law' in its literal legal sense, but instead laws governing the employment relations within an international organization. Professor Amerasinghe correctly put in his treatise: '...the sources of international administrative law or the law governing employment relations in international organizations.4

A debate on the literal legal definition of 'international administrative law', a debate that can be traced back even into the 19th century will be avoided here. ${ }^{5}$ Depending on the background, time and place, (internationales Verwaltungsrecht, diritto internazionale amministrativo, droit international administratif), the meaning of the concept varies greatly. ${ }^{6}$

Properly, therefore, the notion of 'international administrative law' is closer to the concept of 'international institutional law'7 or the so-called Global Administrative Law (GAL), proposed by a research group at New York University. ${ }^{8}$ Both notions are based on the assumption that there is an international public interest (intérêt public international) or global governance which is administered by a set of international rules. GAL, as presented by Professors Kingsbury, Stewart and Krish, covers a wide range of phenomena that present 'administrative' relationships among various stakeholders in the global society. ${ }^{9}$ In that sense, it may not be too wrong to assert that the 'international administrative law', as referred to by IATs, is a small component of GAL. Afterall, IATs perform internal administrative functions in international institutions, with a view to maintaining integrity in their internal employment law system. As long as the

4 Amerasinghe 1988, 102 (emphasis added). Although Chapters 5 to 15 of the book is under a section titled 'Sources of International Administrative Law', the 'Introductory' section of the book, Chapters 1 to 4, only use the term "employment relations in international organizations", instead of "international administrative law".

5 Yamamoto 1967.

6 Von Stein 1982, 23, 37; Rapisardi Mirabelli 1939; Scelle, 'Theorie du gouvernement international' (1935).

7 Bowett 1970. However, Bowett's concept of international institutional law is narrower than that of the author or Yamamoto (see Yamamoto 1967).

$8 \quad$ Kingsbury and others 2005; Kingsbury and Stewart 2012.

$9 \quad$ Kingsbury and others 2005 . 
maintenance of internal employment law can be conceived as a part of international public interest, judges at IATs are executing administrative functions, hence applying a part of GAL. However, 'international administrative law' does not seem to be an appropriate term to define the laws applied by IATs. The fact that IATs are organs of an international administrative institution does not automatically lead us to conclude that they apply international administrative law' in its literal legal sense.

The chapter shall analyze where the problem lies and why this author is uncomfortable when judges refer to the notion of 'international administrative law' in their decisions, under the following headings: Use of the Term 'International Administrative Law' in the Judgments of IATs (Section 2); Sources of 'International Administrative Law' (Section 3); Inaccuracy of the Term 'International Administrative Law' (Section 4); and Application of 'International Administrative Law' in Practice (Section 5); before offering a conclusion (Section 6).

Use of the Term 'International Administrative Law' in Judgments of IATS

This section shall consider the use of the term 'international administrative law', firstly in the decisions of IATs themselves; and second, by the respondent international organizations and applicant international civil servants appearing before IATs.

\subsection{Reference in Various Decisions of IATs by Judges}

A short definition of 'international administrative law' (as referred to in IAT decisions) is, for instance, given in a decision of the United Nations Dispute Tribunal (UNDT) in 2010, according to which "[i]nternational administrative law is the law which regulates the relationship between inter-governmental organizations and their staff members" - without going too much into detail.10 This may be a correct definition of 'international administrative law' known to IATs, but it is silent on the content of the concept. Similarly, the UNDT in a recent decision stated:

The Respondent's refusal to exercise [their] discretion in favour of the Applicant was based on the reasoning that the costing for retroactive promotion was too high and that payment of [a Special Post Allowance]

$10 \quad \mathrm{UNDT}$, Samardzic et al. $v$ Secretary-General of the UN 2010, para 20. 
meant that [their] obligations under international administrative law had been met. Such reasoning and considerations were a complete abdication of the Respondent's responsibilities vis-à-vis the staff member and the correct position of international administrative law.11

The Administrative Tribunal of the International Labour Organization (ILOAT) in a case against the European Patent Office (EPO) mentioned:

The contract with [a collective insurance broker] is [...] to be governed by a German statute of 1908 and by the Civil Code of the Federal Republic of Germany. But such legislation cannot affect relations between the EPO and its staff, which are governed solely by its Service Regulations and the material rules of international administrative law. ${ }^{12}$

The World Bank Administrative Tribunal (WBAT), likewise referred to the concept of 'international administrative law':

Since according to well-established principles of international administrative law, grade should correspond to position and compensation should correspond to grade, the Respondent has not acted in violation of the Applicant's terms of employment in adopting a two-year salary grandfathering. ${ }^{13}$

Most recently, the European Bank for Reconstruction and Development (EBRD) Administrative Tribunal stated:

The Tribunal deliberated the procedural aspects of the decision to terminate the Appellant's employment during the probationary period and concluded that the applicable law (Staff Regulations, the Staff Handbook and general principles of international administrative law) had been applied, and that the decision taken by the Bank was the exercise of its discretionary rights and the procedure applied was taken in compliance with the applicable law. ${ }^{14}$

\footnotetext{
$11 \mathrm{UNDT}$, Elmiv Secretary-General of the UN 2016, para 38.

12 ILOAT, Kasperskiv EPO 1988, para 5.

13 WBAT, Rosario Cardenas $v$ IBRD 1988, para 21.

14 EBRDAT, Applicant $v$ EBRD 2019, para 62 (emphasis added).
} 
The judgments of IATs also provide ample evidence of the widespread use of the term 'international administrative law' amongst the respondent international organizations and applicant international civil servants before them, as we shall see in the next sub-section.

\subsection{Reference by Respondents and Applicants}

Respondents equally refer to the notion of 'international administrative law'. In an ILOAT case, the respondent, the Organization for the Prohibition of Chemical Weapons (OPCW) argued:

If the State Party does not reimburse the OPCW for any national taxation which it has levied, the OPCW will be compelled by international administrative law to reimburse the affected staff member for that amount. ${ }^{15}$

In a UNDT case, the counsel for the respondent,

submitted that a staff member's conduct may extinguish any claim he or she may have concerning the legality of an administrative decision. A staff member may not approbate and reprobate, that is, "blow hot and cold' and that the principles of waiver and estoppel are well-established principles of international administrative law. ${ }^{16}$

Applicants too, appear conversant with 'international administrative law'. In a case of the UNDT, the applicant maintained that,

The Respondent's reliance on the UNIFEm Human Resources Selection Guidelines as a basis for the impugned decision is inconsistent with general principles of international administrative law, and the United Nations hierarchy of properly promulgated instruments. ${ }^{17}$

In an Asian Development Bank Administrative Tribunal case in 2017, an applicant requested: "A written, public apology by ADB to the Applicant for the

\footnotetext{
15 ILOAT, Mr M. L. V OPCW 2003, para 19 (emphasis added).

16 UNDT, Ruyooka $v$ Secretary-General of the UN 2013, para 86 (emphasis added).

17 UNDT, Alquzaa $v$ Secretary-General of the UN 2018, para 4 (emphasis added).
} 
breach of his dignity due to him under the basic principles of international administrative law". 18

\section{Sources of IAL}

While judges and the parties before IATs constantly refer to the notion of 'international administrative law', the Statutes or rules of procedures of IATs themselves have been largely silent on this concept. This is unlike the International Court of Justice (ICJ), for instance, that enumerates clearly in its Statute the laws applied by the Court (in its Article 38). Professor Amerasinghe, after studying meticulously all the constitutive instruments of various IATs, concluded that: "The Statutes of IATs which govern the powers of such tribunals are generally silent in regard to the detailed description of the sources that may be referred to in the application of law to the cases to be decided by them". ${ }^{19}$ This classic text by Professor Amerasinghe has a whole chapter about possible sources of IAL, from staff regulations, staff rules, statutes of tribunals, constitutive instruments, general principles of law, equity, municipal law, judicial precedents, and so forth. ${ }^{20}$

Even if it is accepted that the constitutional instruments of IATs do implicitly have those sources of law in mind, these enumerated sources are not helpful in knowing what sources judges at IATs actually apply when they hear a case. True, they apply contracts of employment, but what legal principles they apply in interpreting the source is not clear. Are they the interpretation rules of the Vienna Convention on the Law of Treaties (VCLT), or are they general principles of law, as mentioned in the ICJ Statute? What seems to be crucial are the legal rules that are used to interpret these sources. More importantly, there seems to be a confusion about the use of 'international administrative law' as a group of norms from which legal rights emerge, on the one hand, and legal principles employed in interpreting or applying the sources of law, on the other. Some judicial decisions and references by both applicants and respondents are using the team 'international administrative law' to mean positive rules to be applied, be they employment contracts or Statutes of IATs, but some others are using the term to show the background for their application, in other words, means by which they come to a legal conclusion or means for interpretation.

18 ADBAT, $M r . H v A D B$ 2017, para 32(e) (emphasis added).

19 Amerasinghe 1988, 108.

20 Ibid, chs $5^{-15}, 101-197$. 
A concrete example could be given in this context: an applicant claims their contract of employment was unlawfully terminated. The Tribunal, after looking into the facts, does not find proof that the management's decision was wrong. However, by a comparison with another employee, who was in the same situation but was not terminated, the Tribunal found that the management's decision was discriminatory, rescinds the termination decision and orders the applicant to be reinstated or be compensated. Here, the secondary source of law is the contract of employment, but the law applied by the Tribunal to come to the conclusion (the primary rule) is perhaps a general principle of law or general international law. The contract of employment might be a source of law (secondary rule), but not a legal rule (primary rule) applied in the judgment.

Confusing the substantive law with the procedural law can easily be demonstrated when case law is referred to as one of the sources of 'international administrative law'. A great number of IAT decisions refer to the decisions of other tribunals or courts. The de Merode case $^{21}$ by the WвAт for example, has been cited in many IATs. ${ }^{22}$ The interpretation methods used by the WBAT to come to its conclusion in this particular case of de Merode cannot have referenced earlier decisions, logically by being the very first in the wвAт. It must have been derived from somewhere, but where?

IATs have not been explicit in answering this question and they have tended simply to refer to 'international administrative law' whenever they could not clearly say what they were applying. When the EBRD Administrative Tribunal states, for instance: "The Tribunal also noted that there is no principle in international administrative law that imposes $100 \%$ of salary be paid in case of service incurred illness", the Tribunal appears to justify its decision by referring to 'international administrative law' because otherwise it may be open to a criticism that the Tribunal made a decision in vacuum..$^{23}$ Likewise, when the WBAT states: "Since according to well-established principles of international administrative law, grade should correspond to position and compensation should correspond to grade", there persists an uncertainty as to the concrete law, with which the Tribunal came to its decision. ${ }^{24}$

\footnotetext{
21 WBAT, Louis de Merode et al. $v$ World Bank 1981.

22 See Imfat, Mr. E. Verreydt v IMF 2016, paras 80, 87 and 106; EBRDAT, Appellant $v$ EBRD 2007, paras 72-73; UNAT, Mirella et al. $v$ Secretary-General of the UN 2018, para 23; ADBAT, Ferdinand P. Mesch and Robert Y. Siy $v A D B$ (No 4) 1997, paras 14, 18, 21, 26, 41 and 45 (and in the Dissenting Opinion).

23 EBRDAT, Appellant $v$ EBRD 2018, para 16.

24 WBAT, Rosario Cardenas $v$ World Bank 1988, para 23.
} 

Law'

In order to show the inadequacy or inaccuracy of using the notion of 'international administrative law', as it is normally used in IATs' decisions, it may be useful to illustrate it by comparing the notion with similar ones. One example can be drawn from the field of 'international economic law'. The Marrakesh Agreement establishing the World Trade Organization (WTO) is undoubtedly the source of law applied in the activities of the wTO, including disputesettlement bodies (DSBS). ${ }^{25}$ However, is it helpful to understand the real picture of the application of DSB (Dispute-settlement Understanding, Annex I of the wTo Agreement) by saying that 'international economic law' is applied in the dispute-settlement body? There is no agreement among the scholars in international law how to understand the whole system of wTO law. The majority view seems to be that WTO is a special regime, a self-contained one, to which the general international law does not directly apply. ${ }^{26}$ What are the rules applied by members of the Panels and the Appellate Body to make their decisions? It is again not helpful to say that 'international economic law' is applied. When the majority view is accepted, namely, that the legal framework of the wTO is a self-contained regime, what is applied there must be a sui generis group of norms derived basically from public international law.

Another example can be given from notion commonly referred to as 'international labor law'. The International Labour Organization (ILO) has adopted nearly 200 international labor conventions in the past 100 years. Maintaining that 'international labor law' is applied in the ILO, or saying that the conventions adopted by the ILO are sources of 'international labor law' is not helpful in understanding the true picture of the applicable rules in the ILO's standardsetting and supervisory activities. There must be a distinctly different set of rules, a part of international legal rules, which are applied in the ILO's activities. One thing is certain that not all of the principles enshrined in the VCLT apply to the ILO (for instance, Reservation to an ILO convention is customarily not permitted). It is a collection of all kinds of administrative acts by the ILO, namely the International Labour Conference, the Governing Body, as well as the supervisory bodies, such as the committees set up in accordance with Articles 24 and 34 of the ILO Constitution and the Committee of Experts on the Application of Conventions and Recommendations, which will eventually establish a coherent set of norms governing the activities of the ILO as an

25 Marrakesh Agreement establishing the wто.

26 Iwasawa 1995, 212-214 (in Japanese). 
international legal entity. ${ }^{27}$ It may be called an international institutional customary law of the ILO, or 'ILO law', but not 'international labor law'.

It would appear that each legal system is in itself a self-contained regime where sui generis law applies. There must be a sui generis group of norms being applied in the IAT regime.

Therefore, the notion of 'international administrative law', used in the context of IATs, is potentially confusing and there is some uneasiness in its use. Professor Amerasinghe in his book discussed quite rightly "the sources of [international administrative law] or the law governing employment relations in international organizations". ${ }^{28}$ The title of his book itself is "The Law of the International Civil Service. The notion of the law of international civil service or law governing employment relations in international organizations is much more convincing.

Having said so, an answer to the question "What is the law governing employment relations in international organizations?" is still to be provided. As a party to the employment contract is an international legal entity, one thing certain is that the contract is not a pure employment law in the domestic law sense. It becomes even closer to an agreement reached within the system of public international law as the employee themselves is an international civil servant, who has a certain degree of immunities from the local law. It follows that public international law applies here, in principle. But which international law? That is a question for which an answer cannot be immediately offered. A tentative submission may be that international administrative tribunals are applying a group of sui generis law, which is a part of public international law or international institutional law, composed of a number of statutory rules, customary international law and case laws of IATs.

Application of 'International Administrative Law' in Practice

There seems to be a tendency for judges at IATs, while not consciously realizing it, to apply sets of legal criteria developed in their own jurisdictions when determining what constitutes the law of employment relationships in

27 The Committee of Experts on the Application of Conventions and Recommendations is not entitled to authoritatively interpret Conventions. Only the ICJ, or a tribunal established for that purpose, has been authorized by the Article 37 of the ILo Constitution. However, throughout its history over go years, supervisory bodies have been continuously applying Conventions in formulating their comments and a sort of case law (administrative case law) has been created therefrom. 
international institutions. As a matter of principle, it is established that IATs do not apply national laws. ${ }^{29}$ However, various national labor law principles concerning unfair labor practices seem to be tacitly applied in some cases without being explicitly referred to. When judges apply laws that are not officially recognized as sources of applicable laws in IATs, they tend to refer to the concept of 'international administrative law', a notion which is not definable.

A very interesting finding was made in a UNDT decision. In 2017, when the UNDT was to judge whether the 'equal pay for equal value of work' principle is to be applied in that particular case, the applicant stated: "This principle of the inclusion of pensions into the concept of equal pay for work of equal value has been accepted in the context of jurisprudence and general International Administrative Law under the Equal Remuneration Convention $1951{ }^{\prime 30}$ The Equal Remuneration Convention $195^{1}$ is an ILO convention and, as such, it cannot bind the UN because the UN cannot ratify it. It is therefore to be assumed that the words 'general International Administrative Law under' had to preface reference to the ILO Convention. This argument seems to maintain that the principle of equal remuneration for equal value of work enshrined in the ILO Convention of 1951 (Number 100) had become customary international law, therefore, it could be used as a source of law in the adjudication of the IATs. The Tribunal, although rejecting the applicant's plea that they should have been entitled to a higher pension payment in their Special Post Allowance position, judged on the basis of the equal remuneration for equal value of work principle, thereby agreeing tacitly to accept application of ILO Convention Number 100, which had been transformed itself into a general international law. The Tribunal even accepted that the remuneration, as defined by the ILO Convention, included also pension payment. ${ }^{31}$ The scope of application of ILO Convention Number 100 and the passage "payable directly or indirectly",32 in particular, was considered by the ILo's supervisory machinery to include pension paid under social security schemes financed by the undertaking. ${ }^{33}$ In a way, the UNDT accepted the 'interpretation' of the Convention by the ILO's supervisory body. This fact makes it difficult to judge whether the Tribunal had applied general international law or whether it did apply the ILO convention directly_probably the latter.

Judges with special expertise in 'ILO law' would be inclined to take the definition of ILO Convention Number 100 on equal remuneration as a criterion to

\footnotetext{
29 Amerasinghe 1988, 175.

30 UNDT, Glavind $v$ Secretary-General of the UN 2017, para 26 (emphasis added).

31 Ibid.

32 Equal Remuneration Convention, art 1(a).

33 ILO, 'General Survey' 1986, para 17.
} 
define wages, if the scope of wages were at stake. However, even judges receptive to 'ILO law' would hesitate to apply ILO Convention Number $158^{34}$ - on the termination of employment at the initiative of the employer-before an IAT. For this sets quite a high burden on employers and perhaps not enforceable as general international law. Convention Number 10o, on the other hand, is one of the fundamental conventions of the ILO, which can be construed as pronouncing established customary law. The same applies to other fundamental ILo Conventions, such as one on non-discrimination in employment and occupation (Number 111$)^{35}$ or another on the prohibition of forced or compulsory labor (Number 29). ${ }^{36}$

\section{6}

\section{Conclusion}

It would be appropriate to recapitulate the findings made so far. The applicable law in IATs, the law governing employment relations in international organizations, is composed of the following: (i) substantive rules, such as employment contracts, staff regulations, staff rules, administrative orders; and (ii) procedural and interpretative rules, such as statutes of tribunals, general principles of law (such as estoppel, good faith, equity, non-abuse of rights, due process), customary international law (including certain human rights principles, such as non-discrimination), judicial precedents (of other courts, both national as well as international, including other IATs — as far as they are consistent with customary international law). The last qualification-consistency with customary international law-is important. Judicial decisions of national courts or regional courts, such as the European Court of Human Rights, and of other IATs are valid laws applicable in IATs, basically to the extent that they reflect established rules in customary international law. For other courts' decisions, those of national courts, in particular, have no res judicata on IATs.

On the other hand, it is an undisputed reality that judges refer to other IAT's decisions and more generally to 'international administrative law', whenever they have difficulties identifying concrete rules to support their arguments. This is not inappropriate. As adjudications always have law-making elements, some of the findings of IATS may have a law-creating factor. The WTO's DSB, as well as the ILO's supervisory bodies do create a sort of sui generis rules, which had not existed before the establishment of the organization concerned. What

34 Termination of Employment Convention.

35 Discrimination (Employment and Occupation) Convention.

36 Forced Labour Convention. 
is called 'wTo law' or 'international institutional law of the ILO' (or 'ILO Law') aforementioned in this chapter, is not only composed of black letter laws, but also of newly emerging principles of law that spring up from the daily activities of the organizations, a spontaneous law of international organizations.

So, the answer to the question raised at the very beginning of this chapter would be that 'international administrative law' is a potentially misleading concept when referred to in the judgments of IATs, because there is no such thing as an a priori 'international administrative law'. However, a look at the whole legal framework of adjudication in the internal justice system of international organizations makes us assume that there is an emerging group of legal norms within the specific regime of IATs, which can be called the 'Law Governing Employment Relations in International Organizations', or 'International Civil Service Law'. It is a group of sui generis law, basically rooted in public international law or 'international institutional law', applying to the specific legal regime of the international civil service.

\section{Reference List}

Alquzaa $v$ Secretary-General of the United Nations, UNDT Order No 012 (NBI/2018) (2018).

Amerasinghe C F, The Law of International Civil Service Volume I (Clarendon 1988).

Appellant v European Bankfor Reconstruction and Development, EBRDAT Decision on Case 2006/AT/o4 (liability) (2007).

Appellant $v$ European Bank for Reconstruction and Development, EBRDAT Decision on Case 2018/AT/o6 (2019).

Appellant v European Bank for Reconstruction and Development, EBRDAT Decision on Case 2018/AT/01+04 (Decision) (2018).

Bowett D W, The Law of International Institutions (Stevens 1970).

Constitution of the International Labour Organization (adopted in April 1919, entered into force 28 June 1919).

Discrimination (Employment and Occupation) Convention (adopted 25June 1958, entered into force 15 June 1960) ILO Convention No 111.

Elmi $v$ Secretary-General of the United Nations, UnDT Judgment No UNDT/2016/032 (2016).

Equal Remuneration Convention (adopted 29 June 1951, entered into force 23 May 1953), ILO Convention No 100.

Ferdinand P. Mesch and Robert Y. Siy v Asian Development Bank (No 4), АDBAт Decision No 35 (1997). 
Forced Labour Convention (adopted 28 June 1930, entered into force 1 May 1932) ILO Convention No 29.

Glavind $v$ Secretary-General of the United Nations, UnDT Judgment No UNDT/2017/053 (2017).

International Labour Office of the International Labour Organization, 'General Survey of the Reports on the Equal Remuneration Convention (No. 100) and Recommendation (No. 9o), 1951', (International Labour Conference 72nd Session, 1986, Report III (Part 4B)) <https://www.ilo.org/public/libdoc/ilo/P/og661/og661(1986-72-4B).pdf> accessed on 2 March 2020.

Iwasawa Y, Dispute settlement at the WTO (Sanseido 1995)

Kasperski v European Patent Office, ILOAT Judgment No 944 (1988).

Kingsbury B and others, 'The Emergence of Global Administrative Law' (2005) 68 Law and Contemporary Problems 15.

Kingsbury B and Stewart R, 'Administrative Tribunals of International Organizations, from the Perspective of the Emerging Global Administrative Law' in Elias O (ed), The Development and Effectiveness of International Administrative Law (Brill 2012).

Louis de Merode et al. $v$ The World Bank, wBAт Decision No 1 (1981).

Marrakesh Agreement establishing the World Trade Organization (adopted 15 April 1994, entered into force 1 January 1995) 1867 UNTS 3.

Mirella et al. $v$ Secretary-General of the United Nations, UnAT Judgment No 2018-UNAT842 (2018).

Mr. E. Verreydt v International Monetary Fund, I M FAT Judgment No 2016-5 (2016).

Mr. Hv Asian Development Bank, ADBAT Decision No 108 (2017).

Mr M.L. v Organisation for the Prohibition of Chemical Weapons, ILOAT Judgment No 2256 (2003).

Rapisardi Mirabelli A, Il diritto internazionale amministrativo (CEDAM, 1939).

Rosario Cardenas v The World Bank, wBAT Decision No 71 (1988).

Samardzic et al. $v$ Secretary-General of the United Nations, UNDT Judgment No UNDT/2010/019 (2010).

Scelle G, 'Le phénomène juridique du dédoublement fonctionnel', in Schatzel W and Schlochauer HJ (eds), Rechtsfragen der Internationalen Organisationen-Festschrift für H. Wehberg (Klostermann 1956).

Scelle G, 'Theorie du gouvernement international' in (1935) Annuaire de l'Institut International du Droit Public, 41.

Termination of Employment Convention (adopted 22 June 1982; entered into force 23 November 1985) ILO Convention No $15^{8}$.

Von Stein L, 'Einige Bemerkungen über das international Verwaltungsrecht, Schmollers Jahrbuch fur Gesetzgebung', (1982) 6 Verwaltung und Volkswirtschaft 1, 23. 
Yamamoto S, 'The Positive Basis of International Administrative Law', (1967) 76 Kokusaihou Gaiko Zasshi (The Journal of International Law and Diplomacy 1) 1 (in Japanese).

Yassin Abdullah Kadi, Al Barakaat International Foundation $v$ Council of the European Union et al., European Court of Justice Judgment on Joined Cases C-402/05 P and C-415/05 P (2008). 